\title{
ANALYSIS OF THE TRUTH IN ADVERTISING ON THE EFFICACY PROVIDED BY ASSISTED REPRODUCTION CLINICS
}

\author{
Juan Aznar ${ }^{1}$, Julio Tudela ${ }^{1}$, Justo Aznar ${ }^{1}$
}

\begin{abstract}
This paper analyses the efficacy data from assisted reproduction clinics, obtained from both scientific society reports and from studies published in specialised journals, in order to compare them with information published by Spanish assisted reproduction clinics on their websites. It aims to verify whether this information matches the reality of the findings in the media analysed or, in contrast, differs from the aforementioned scientific evidence. Our study shows marked discrepancies between the evidence of existing statistical data, and figures published by most of the clinics on their websites, which could constitute false advertising.
\end{abstract}

Key words: assisted reproduction clinics, live birth rate, pregnancy rate, in-vitro fertilisation, intracytoplasmic sperm injection, false advertising

\section{Análisis sobre la autenticidad de la publicidad sobre la eficacia de clínicas de reproducción asistida}

Resumen: Este estudio analiza los datos de eficacia de clínicas de reproducción asistida, obtenidos tanto de informes de sociedades científicas como de estudios publicados en revistas especializadas, para compararlos con la información publicada por las clínicas de reproducción asistida de España en sus sitios web. El objetivo es verificar si esta información es conforme a los hallados en informes y revistas o, por el contrario, difiere de la evidencia científica mencionada. Nuestro estudio demuestra marcadas discrepancias entre la evidencia de datos estadísticos existentes y las cifras publicadas por la mayoría de los sitios web de las clínicas, lo cual constituye falsa publicidad.

Palabras clave: clínicas de reproducción asistida, frecuencia de nacimientos vivos, frecuencia de embarazos, fecundación in vitro, inyección intracitoplásmica de espermatozoides, publicidad falsa

\section{Análise da verdade na publicidade sobre a eficácia fornecida pelas clínicas de reproduçáo assistida}

Resumo: Este artigo analisa os dados de eficácia de clínicas de reprodução assistida, obtidas de relatórios da sociedade científica e de estudos publicados em revistas especializadas, a fim de compará-los com informaçóes publicadas por clínicas de reprodução assistida espanholas em seus websites. $\mathrm{O}$ artigo visa verificar se esta informação coincide com a realidade dos resultados encontrados nos meios de comunicaçáo analisados ou, por outro lado, difere da evidência científica acima mencionada. Nosso estudo mostra discrepâncias entre a evidência dos dados estatísticos existentes e indicadores publicados pela maioria das clínicas em seus sites, que podem constituir falsa publicidade.

Palavras-chave: clínicas de reprodução assistida, taxa de natalidade, taxa de fecundidade, fertilização in vitro, injeção intracitoplasmática de espermatozoide, false publicidade

\footnotetext{
${ }^{1}$ Instituto de Ciencias de la Vida. Universidad Católica de Valencia, Espańa

Correspondencia: justo.aznar@ucv.es
} 


\section{Introduction}

A major tool used by assisted human reproduction clinics (AHRC) to attract clients is to show - through their websites - their efficacy in helping women who attend them to have a muchdesired child. One ethical problem that may arise, however, is whether this advertising is based on proven scientific data, for if this is not the case, it might be thought that the clinics were using "false advertising" to achieve their ends. The aim of this study was to evaluate this.

To this end, the pregnancy and live birth rates provided by various scientific associations were reviewed and compare with those presented by the aforementioned clinics on their websites and brochures, in order to check whether or not there are discrepancies between both data sources. We also studied the cumulative pregnancy and live birth rates, with particular emphasis on the latter, since the cumulative live birth rate is what should - in our opinion - be more consistent with the percentages presented by clinics regarding the possibility of having a child.

\section{Materials and methods}

In this study, we looked at the pregnancy and live birth rates in three geographical areas using various sources: in Spain, for which we used European Society of Human Reproduction and Embryology (ESHRE) and Spanish Fertility Society (SEF) annual reports; in Europe, for which we used ESHRE annual reports from 1997 to 2010; and globally, for which we used articles from scientific journals, such as:

Human Reproduction, Reproductive BioMedicine, Fertility and Sterility, The New England Journal of Medicine, The Lancet and the British Journal of Obstetrics and Gynaecology.

The information presented by Spanish AHRC to their clients was obtained from a review of their websites between 19th and 29th May, 2015.

\section{Results}

1. Pregnancy and live birth rates in Europe per ovarian stimulation cycle

\subsection{In-vitro fertilisation}

The pregnancy rate (PR) and live birth rate (LBR) following in-vitro fertilisation (IVF) in Europe between 1997 and 2010 were first determined based on data published by the ESHRE in 2014 (Table 1)(1-14). The PR varied between $22.28 \%$ and $29.2 \%$, with a mean rate of $26.41 \%$, while the LBR varied between $13.07 \%$ and $22.4 \%$, with a mean rate of $18.81 \%$.

One interesting aspect of our study was to compare the trend in these indices in the 14 years evaluated. With the exception of the 1997 LBR (which was $13.07 \%$ ), the other indices varied very little over the years, and in fact did not exceed 6.92 percentage points for the PR and 5.8 points for the LBR (if the 1997 rate is excluded). It should also be highlighted that, if data from the last five years only is considered, the PR varied by 0.7 percentage points, and the LBR by 1.8 points. These figures show the scant improvement achieved in recent years in both types of indices, despite advances in technical procedures in the same time period.

\subsection{Intracytoplasmic sperm injection}

Making a similar assessment to the one carried out with IVF, it was found that when intracytoplasmic sperm injection (ICSI) was used (Table 1), the PR varied between $23.37 \%$ and $29.9 \%$, with a mean rate of $27.22 \%$, while the LBR varied between $12.68 \%$ and $21.10 \%$, with a mean rate of $18.31 \%$.

As with IVF, the PR and LBR obtained between 1998 and 2010 when ICSI was used had a maximum variation of between 5.1 and 4.93 percentage points, respectively; even if data from the period 2006-2010 only were considered, the PR decreased by $1.1 \%$ and the LBR increased by 2.7 $\%$. In other words, as with IVF, both rates (PR and LBR) scarcely varied in the years evaluated, despite possible technical improvements in both IVF and ICSI. 
Table 1: Pregnancy and live birth rates with IVF and ICSI in Europe from 1997 to 2010 after one stimulation cycle (ESHRE annual reports).

\begin{tabular}{|c|c|c|c|c|c|}
\hline \multirow{2}{*}{ YEAR } & \multirow{2}{*}{ Reference } & \multicolumn{2}{|c|}{ IVF } & \multicolumn{2}{|c|}{ ICSI } \\
\cline { 3 - 6 } & & $\begin{array}{c}\text { Pregnancy rate } \\
(\%)\end{array}$ & Live birth rate (\%) & $\begin{array}{c}\text { Pregnancy rate } \\
(\%)\end{array}$ & Live birth rate (\%) \\
\hline 1997 & $(1)$ & 22.28 & 13.07 & 23.37 & 12.68 \\
\hline 1998 & $(2)$ & 23.20 & 16.60 & 24.80 & 17.03 \\
\hline 1999 & $(3)$ & 24.20 & 17.00 & 26.10 & 16.17 \\
\hline 2000 & $(4)$ & 24.70 & 18.60 & 26.60 & 19.05 \\
\hline 2001 & $(5)$ & 25.10 & 18.67 & 26.20 & 19.07 \\
\hline 2002 & $(6)$ & 26.00 & 18.70 & 27.20 & 19.74 \\
\hline 2003 & $(7)$ & 26.10 & 17.61 & 26.50 & 17.74 \\
\hline 2004 & $(8)$ & 26.60 & 17.92 & 27.10 & 17.29 \\
\hline 2005 & $(9)$ & 26.90 & 18.32 & 28.50 & 18.10 \\
\hline 2006 & $(10)$ & 29.00 & 21.50 & 29.90 & 18.40 \\
\hline 2007 & $(11)$ & 29.10 & 21.10 & 28.60 & 20.20 \\
\hline 2008 & $(12)$ & 28.50 & 21.20 & 28.70 & 20.40 \\
\hline 2009 & $(13)$ & 28.90 & 20.60 & 28.70 & 19.30 \\
\hline 2010 & $(14)$ & 29.20 & 22.40 & 28.80 & 21.10 \\
\hline Mean rate & & 26.41 & 18.81 & 27.22 & 18.31 \\
\hline & & & & & \\
\hline & $(19)$ & & & & \\
\hline
\end{tabular}


Analysis of the truth in advertising on the efficacy provided by assisted reproduction clinics - Juan Aznar et al.

Table 2: Pregnancy and live birth rates with IVF in Spain from 1997 to 2010 after one stimulation cycle (ESHRE annual reports).

\begin{tabular}{|c|c|c|c|c|c|}
\hline \multirow{2}{*}{ Year } & \multirow{2}{*}{ Reference } & \multicolumn{2}{|l|}{ IVF } & \multicolumn{2}{|l|}{ ICSI } \\
\hline & & Pregnancy rate (\%) & Live birth rate (\%) & Pregnancy rate (\%) & Live birth rate (\%) \\
\hline 1997 & (1) & 23.20 & & 29.50 & \\
\hline 1998 & (2) & 23.00 & 17.40 & 26.70 & 19.50 \\
\hline 1999 & (3) & 26.20 & & 32.40 & 25.60 \\
\hline 2000 & (4) & 28.80 & 17.60 & 32.10 & 20.10 \\
\hline 2001 & (5) & 28.70 & 19.20 & 30.60 & 21.00 \\
\hline 2002 & (6) & 32.70 & 21.70 & 35.20 & 22.50 \\
\hline 2003 & (7) & 32.80 & 17.90 & 35.40 & 17.00 \\
\hline 2004 & (8) & 31.80 & 14.50 & 32.50 & 16.00 \\
\hline 2005 & (9) & 30.70 & 10.40 & 33.10 & 14.60 \\
\hline 2006 & (10) & 34.90 & 30.60 & 34.00 & 17.60 \\
\hline 2007 & (11) & 34.60 & & 33.60 & \\
\hline 2008 & (12) & 31.50 & 18.40 & 34.60 & 20.00 \\
\hline 2009 & (13) & 35.00 & 20.00 & 33.90 & 19.20 \\
\hline 2010 & (14) & 33.80 & 17.50 & 32.70 & 19.70 \\
\hline Mean rate & & 30.55 & 18.65 & 32.59 & 19.40 \\
\hline
\end{tabular}

2. Pregnancy and live birth rates in Spain

Both rates were obtained using ESHRE (14) and EFSEF data(15).

\subsection{In-vitro fertilisation}

IVF data for Spain provided by the ESHRE for the period 1997 to 2010 (Table 2) were first evaluated. The PR varied between $23.0 \%$ and 35.0 $\%$, with a mean rate of $30.55 \%$, while the LBR varied between $17.4 \%$ and $30.6 \%$, with a mean rate of $18.65 \%$. As can be seen, the mean PR in Spain $(30.55 \%)$ is notably higher than the European mean $(27.22 \%)$, which certainly indicates the technical quality of Spanish AHRC.

\subsection{Intracytoplasmic sperm injection}

When the same analysis was carried out for ICSI, the PR per ovarian stimulation cycle varied between $26.7 \%$ and $35.4 \%$, with a mean of 32.5 $\%$ (Table 2); the LBR was lower, varying between $14.6 \%$ and $25.6 \%$, with a mean of $19.4 \%$.

In the 14 years covered by this study, variability for both indices was between 8.7 percentage points for the PR and 9.6 points for the LBR.

2.3. Data for Spain for the years 2011 and 2012 
In addition to the data for Spain obtained from the ESHRE, the SEF also published data for 2011 and 2012(15).

\subsubsection{In-vitro fertilisation}

The PRs for those years were $32.7 \%$ (2011) and
$33.5 \%$ (2012), while the LBRs were $17.3 \%$ and $19.4 \%$, respectively(15).

Notably, the statistics provided by the ESHRE for these last two years were no better than the those of the previous 14 - and in fact were even worse - clearly indicating that, as in previous years, the

Table 3: CLBR according to various authors

\begin{tabular}{|c|c|c|c|c|c|c|}
\hline \multirow{2}{*}{ AUTHOR } & \multirow{2}{*}{ REFERENCES } & \multicolumn{5}{|c|}{ LIVE BIRTH RATE } \\
\hline & & 1 cycle $\%$ & 2 cycles $\%$ & 3 cycles $\%$ & $>3$ cycles $\%$ & Overall \% \\
\hline Tan & (18) & & & & 45.0 (a) & \\
\hline Engmann & (19) & 20.0 & 33.2 & 48.2 & & 51.3 \\
\hline Stolwijk* & (20) & & & & & $54.5^{*}$ \\
\hline Kovacs & (21) & $20.7^{*}$ & & & & \\
\hline Schröder & (22) & & & & & $51.2^{*}$ \\
\hline Pellink & (23) & & & & & 50.5 \\
\hline Stern & (24) & 30.4 & 43.3 & 49.1 & 51.9 a $53.8(b)$ & \\
\hline Gnoth & (25) & & & 52.0 & $85(c)$ & \\
\hline Setti & (26) & & & 53.3 & 73.8 (d) & \\
\hline Malizia & (27) & & & 53.2 & & \\
\hline Stern & (28) & & & & & 62,1 \\
\hline Smith & (29) & 29.5 & & & $65.3(\mathrm{e})$ & 68.4 \\
\hline Ishihara & (30) & & & 28.5 & & \\
\hline Mean rate & & 26.6 & 38.3 & 47.4 & 66.0 & 56.3 \\
\hline \multicolumn{7}{|c|}{${ }^{*}$ Data on pregnancy rate $(\mathrm{PR})$, not cumulative live birth rate (CLBR). Not included in the calculation of the mean rate. } \\
\hline \multicolumn{7}{|c|}{ a) This rate was obtained after five stimulation cycles } \\
\hline \multicolumn{7}{|c|}{ b) After eight cycles } \\
\hline \multicolumn{7}{|c|}{ c) After twelve cycles } \\
\hline \multicolumn{7}{|c|}{ d) After six cycles } \\
\hline & & & After six cyc & & & \\
\hline
\end{tabular}


efficacy of the technique did not improve in that time.

One fact to highlight is that in Spain, the LBRs are markedly lower than the PRs. We have no reasonable explanation for this, although it does not have any bearing on our paper since it is not the specific aim of this study.

\subsubsection{Intracytoplasmic sperm injection}

When the same data were analysed for ICSI, the PR corresponding to those two years was 31.7 $\%$ and $31.0 \%$, while the LBR was $18.8 \%$ and $18.1 \%$, respectively.

\section{Cumulative pregnancy and live birth rates}

The efficacy of assisted human reproduction techniques using IVF and ICSI has until now generally evaluated the pregnancy and live birth rate per stimulation cycle. However, these rates do not appear to be the most appropriate, because when a couple attend an assisted procreation clinic, they basically want to know the likelihood of having a child after one or several stimulation cycles. This technically corresponds to the cumulative live birth rate (CLBR).

The cumulative pregnancy rate (CPR) can also be used, i.e. the likelihood, expressed in percentage, that a woman will become pregnant following several stimulation cycles. However, since obviously not all pregnancies go full term, ending with the birth of a child, we consider the CLBR to be the most appropriate index for evaluating the efficacy of these methods.

To that end, we evaluated the CLBR obtained in various studies and under different circumstances, such as the woman's age, whether fresh or frozen oocytes were used, whether these were autologous or donor oocytes, cause of the infertility and other circumstances.

As shown in Table 3, several studies that provided objective data on the CLBR were conducted since the beginning of the 1990s. Several of these found that the woman's age decisively affected the rates when autologous oocytes are used. Other studies not included in this Table confirm this $(16,17)$.
We believe that these should be taken into consideration, since increasingly older women are now attending AHRCs to have a child. Accordingly, the CPR and CLBR obtained in women over 38 years could be more relevant to the standard practice of these techniques.

In 2010, Gelbaya performed a systematic review and meta-analysis that evaluated the CLBR in relation to whether one or two embryos had been transferred(31), finding that, in a study by Thurin et al.(32), the CPR after three stimulation cycles was $38.8 \%$ when one embryo was transferred, and $42.9 \%$ when two embryos were transferred. Lukassen et al. obtained rates of $40.7 \%$ and $38.5 \%$ respectfully(33), while Moustafa et al. found rates of $45.0 \%$ and $46.3 \%(34)$. A study by Heijnen found rates of $43.4 \%$ and $44.7 \%$, respectively, in women who had received up to a maximum of four treatment cycles, after moderate ovarian stimulation(35). In other words, until 2010, the overall CPRs and CLBRs continued to hover around $50 \%$.

Another large study continued to show that when autologous oocytes were used, the CLBR decreased with the woman's age. Thus, the CLBR obtained after three stimulation cycles was 63.3 $\%$ for women under 31 years, $18.6 \%$ for those aged between 41 and 42 years, and $6.6 \%$ for those aged 43 years or older(36). When donor oocytes were used, the overall CLBR varied between 50 $\%$ and $55 \%$, i.e. very similar to that obtained in previous studies. However, in addition to the specific outcomes mentioned, it should be highlighted that in this last study, the authors used data provided by the Society for Assisted Reproductive Technology Clinic Outcome Reporting System, which collected information between 2004 and 2009 from more than $90 \%$ of AHRC in the United States. The number of women evaluated was therefore very high $(246,740)$, as was the number of live births $(140,859)$. It should also be noted that these data were verified by the Centers for Disease Control and Prevention (CDC) and the Fertility Clinic Success Rate and Certification Act, which attests to their validity.

Also in 2013, Stern et al. again studied the CLBR in relation to the cause of the infertility that led the patient to consult the AHRC, making spe- 
cial reference to diminished ovarian reserve. They found that in women with diminished reserve, the CLBR was only $28.3 \%$, but that other causes of infertility barely affected this rate, which in this group of women was $62.1 \%(28)$.

In 2015, one study found that no age-dependent differences were observed when donor oocytes were used(29).

In our view though, the most complete information on CLBR (following IVF or ICSI) undoubtedly comes from a report by the International Committee for Monitoring Assisted Reproductive Technologies: World Report on Assisted Reproductive Technologies(30), which included $1,251,881$ assisted reproduction interventions, collecting data from 2419 clinics in 55 countries. Although the Report was published in February 2015, the data evaluated correspond to 2007.

The most important point in the study by Ishihara et al. is that the overall CLBR was $28.5 \%$; this is the percentage that expresses, among all the clinics evaluated, the likelihood that a woman can have the desired child.

These rates naturally vary significantly among countries, the highest being found in the United States $(41.8 \%)$ and the lowest in Bosnia-Herzegovina $(12.7 \%)$.

Obviously, we cannot go into detail here on the CLBRs in the 55 countries included in the study, but those with the largest economic development are clearly those with the highest CLBR (Table 4).

Aside from the data on individual countries indicated here, it is interesting to highlight the CLBR by continental groups, which in Europe was 24.6 $\%$, in Asia $17.8 \%$, in Australia and New Zealand $30.8 \%$, in Latin America $26.0 \%$, and in North America $40.8 \%$; the global overall CLBR, as previously mentioned, was $28.5 \%$.

4. Outcomes provided by Spanish assisted human reproduction clinics regarding the likelihood that a woman attending them will have a child

When evaluating AHRCs in Spain, it is interesting to differentiate between public and private clinics. In order to elicit the outcomes provided
Table 4: CLBR in several developed countries 2007(30).

\begin{tabular}{|c|c|}
\hline COUNTRY & CLBR ( \%) \\
\hline Spain & 22.9 \\
\hline Belgium & 26.2 \\
\hline Denmark & 24.7 \\
\hline Sweden & 31.8 \\
\hline Norway & 31.3 \\
\hline France & 23.7 \\
\hline Germany & 20.1 \\
\hline Italy & 18.3 \\
\hline Holland & 26.7 \\
\hline Poland & 36.5 \\
\hline Russia & 24.7 \\
\hline United Kingdom & 31.6 \\
\hline Canada & 38.1 \\
\hline United States & 41.8 \\
\hline
\end{tabular}

by AHRCs on their websites, 169 web pages were analysed; this represents 278 clinics, $27.22 \%$ of which were public, while $72.78 \%$ were private.

\section{Outcomes provided by public AHRCs}

Of the 46 Spanish public clinics that offer assisted human reproductive techniques, we were able to obtain success rates for only three. The most reliable statistics were presented by Hospital Universitario Virgen de las Nieves, Granada, with a PR following IVF of $32.8 \%$ in 2014 (37). The mean PR in the three clinics was $35.3 \%$. Remarkably, although all of these public clinics have participated in the SEF data register in recent years, none have publically reported their success rates. 
Analysis of the truth in advertising on the efficacy provided by assisted reproduction clinics - Juan Aznar et al.

Outcomes provided by private AHRCs

The data obtained from private AHRCs are very different. Of the 123 private clinics that we analysed, $48.78 \%$ published some information on their PRs, but interestingly, none published in- formation on the rate per cycle or CLBR, which is very surprising.

All the information is shown in Table 5, where it can be seen that, as regards the private clinics, the CPR with autologous oocytes following one

Table 5: Information presented by the websites of Spanish private AHRCs.

\begin{tabular}{|c|c|c|c|c|c|c|c|c|}
\hline \multirow[b]{2}{*}{ PRIVATE AHRC } & \multicolumn{4}{|l|}{1} & \multirow{2}{*}{\begin{tabular}{|l|}
2 \\
$(\%)$
\end{tabular}} & \multirow{2}{*}{\begin{tabular}{|l|}
3 \\
$(\%)$
\end{tabular}} & \multirow{2}{*}{\begin{tabular}{|l|}
4 \\
$(\%)$
\end{tabular}} & \multirow{2}{*}{\begin{tabular}{|l|}
5 \\
$(\%)$
\end{tabular}} \\
\hline & $\begin{array}{l}\text { Overall } \\
(\%)\end{array}$ & $\begin{array}{l}<35 \\
\text { years }(\%)\end{array}$ & $\begin{array}{l}35-39 \text { years } \\
(\%)\end{array}$ & $\begin{array}{l}\geq 40 \\
\text { years }(\%)\end{array}$ & & & & \\
\hline $\begin{array}{l}\text { Barcelona IVF (http://www. } \\
\text { barcelonaivf.com) }\end{array}$ & & & & & & & & $\mathrm{X}$ \\
\hline $\begin{array}{l}\text { Embriogyn (http://www.embriogyn. } \\
\text { com) }\end{array}$ & 52.0 & & & & 63.7 & & & \\
\hline $\begin{array}{l}\text { Ginefiv } \\
\text { (http://www.ginefiv.com) }\end{array}$ & & 60.0 & 50.0 & 35.0 & 60.0 & 85.0 & $\mathrm{X}$ & \\
\hline $\begin{array}{l}\text { CEFIVBA } \\
\text { (http://www.cefivba.com) }\end{array}$ & 37.7 & & & & 44.4 & & $\mathrm{X}$ & \\
\hline $\begin{array}{l}\text { ProcreaTec (http://www.procreatec. } \\
\text { com) }\end{array}$ & & 50.0 & 32.0 & 18.0 & 69.0 & 90.0 & & \\
\hline $\begin{array}{l}\text { Grupo Hospitalario Quirón (http:// } \\
\text { www.quiron.es) }\end{array}$ & 28.0 & & & & & & & \\
\hline $\begin{array}{l}\text { FIV CENTER (http://www. } \\
\text { fivcenter.com) }\end{array}$ & 50.0 & 52.0 & 46.0 & 33.0 & & & & \\
\hline $\begin{array}{l}\text { Gravida. Fertilitat Avançada } \\
\text { (http://www.gravidabcn.com) }\end{array}$ & 49.2 & 70.4 & 43.7 & 34.2 & 71.0 & & & \\
\hline $\begin{array}{l}\text { Institut Conceptum (http://www. } \\
\text { conceptum.es) }\end{array}$ & 49.0 & & & & & 90.0 & $\mathrm{X}$ & \\
\hline $\begin{array}{l}\text { FecunMed (http://www.fecunmed. } \\
\text { com) }\end{array}$ & 49.6 & 63.6 & 41.2 & 34.8 & 58.0 & & & \\
\hline $\begin{array}{l}\text { Instituto Murciano de Fertilidad } \\
\text { (IMFER)(http://www.imfer.com) }\end{array}$ & & 53.0 & 39.0 & 26.0 & 57.0 & 90.0 & $\mathrm{X}$ & \\
\hline $\begin{array}{l}\text { Clínica Sanabria } \\
\text { (http://www.clinicasanabria.com) }\end{array}$ & & 50.0 & & 20.0 & & & & \\
\hline $\begin{array}{l}\text { Clínica IMF Madrid } \\
\text { (http://www.imfertilidad.com) }\end{array}$ & 52.0 & 62.0 & 47.0 & 31.0 & & 90.0 & $\mathrm{X}$ & $\mathrm{X}$ \\
\hline $\begin{array}{l}\text { Biogest } \\
\text { (http://www.biogest.es) }\end{array}$ & 40.0 & & & & & & & \\
\hline $\begin{array}{l}\text { HM Fertility Center (http://www. } \\
\text { hmfertilitycenter.com) }\end{array}$ & & & & & 60.0 & 90.0 & $\mathrm{X}$ & \\
\hline $\begin{array}{l}\text { Instituto Bernabeu (http://www. } \\
\text { institutobernabeu.com) }\end{array}$ & & 79.9 & 72.0 & 48.6 & 84.5 & 95.0 & $\mathrm{X}$ & \\
\hline $\begin{array}{l}\text { Clínica Mencia (http://www. } \\
\text { clinicamencia.com) }\end{array}$ & 45.0 & & & & & 80.0 & & \\
\hline $\begin{array}{l}\text { Grupo Hospitalario Quirón } \\
\text { (Barcelona) (http://www.barcelona- } \\
\text { reproduccion.quiron.es) }\end{array}$ & 50.0 & 56.0 & 40.3 & 21.3 & 68.0 & & & \\
\hline $\begin{array}{l}\text { TAHE Fertilidad (http://www. } \\
\text { tahefertilidad.es) }\end{array}$ & & 45.0 & 40.0 & 32.0 & 58.0 & & & \\
\hline
\end{tabular}


Acta Bioethica 2017; 23 (2): 311-325

\begin{tabular}{|c|c|c|c|c|c|c|c|c|}
\hline \multirow[b]{2}{*}{ PRIVATE AHRC } & \multicolumn{4}{|l|}{1} & \multirow{2}{*}{2} & \multirow{2}{*}{3} & \multirow{2}{*}{$\begin{array}{l}4 \\
(\%)\end{array}$} & \multirow{2}{*}{$\begin{array}{l}5 \\
(\%)\end{array}$} \\
\hline & $\begin{array}{l}\text { Overall } \\
(\%)\end{array}$ & $\begin{array}{l}<35 \\
\text { years }(\%)\end{array}$ & $\begin{array}{l}35-39 \text { years } \\
(\%)\end{array}$ & $\begin{array}{l}\geq 40 \\
\text { years }(\%)\end{array}$ & & & & \\
\hline $\begin{array}{l}\text { FIV VALENCIA } \\
\text { (http://www.fiv-valencia.es) }\end{array}$ & 47.0 & & 60.0 & & & 90.0 & $\mathrm{X}$ & \\
\hline $\begin{array}{l}\text { Clínica Tambre } \\
\text { (http://wwwclinicatambre.com) }\end{array}$ & & 52.5 & 44.2 & 33.8 & 65.0 & & & \\
\hline $\begin{array}{l}\text { CREA } \\
\text { (http://www.creavalencia.com) }\end{array}$ & & 50.8 & 45.3 & & 68.4 & & & \\
\hline $\begin{array}{l}\text { URE Centro Gutenberg (http:// } \\
\text { www.urecentrogutenberg.es) }\end{array}$ & & $57.0 \%$ & 49.0 & 37.0 & & 75.0 & & \\
\hline $\begin{array}{l}\text { Girexx } \\
\text { (http://www.girexx.es) }\end{array}$ & 48.0 & 48.0 & 34.0 & 34.0 & 58.0 & & & \\
\hline $\begin{array}{l}\text { Institut Marquès (http://www. } \\
\text { institutomarques.com) }\end{array}$ & 72.2 & 82.4 & 77.8 & 41.1 & 63.2 & & & \\
\hline $\begin{array}{l}\text { Clínica Montpellier (http://www. } \\
\text { clinicamontpellier.com) }\end{array}$ & 35.0 & & & & 50.0 & 80.0 & & \\
\hline $\begin{array}{l}\text { Instituto para el Estudio } \\
\text { de la Esterilidad (http:// } \\
\text { wwwestudioesterilidad.com) }\end{array}$ & 60.0 & & & & 80.0 & & & \\
\hline $\begin{array}{l}\text { Unidad de Fertilidad de Almoradí- } \\
\text { Alicante (UFEAL) } \\
\text { (http://www.ufeal.com) }\end{array}$ & 40.0 & & & & & & & \\
\hline $\begin{array}{l}\text { CEFIVA Centro de Fertilización In } \\
\text { Vitro de Asturias (http://www.cefiva. } \\
\text { com)/es/ }\end{array}$ & 36.8 & 55.0 & 42.4 & 23.4 & & & & \\
\hline $\begin{array}{l}\text { Unidad de Reproducción Clínica } \\
\text { Vistahermosa (http://www. } \\
\text { urvistahermosa.com)/es/ }\end{array}$ & 60.0 & 70.0 & & & & 80.0 & $\mathrm{X}$ & \\
\hline $\begin{array}{l}\text { Clínica Medrano (http://www. } \\
\text { clinicamedrano.com)/ }\end{array}$ & 40.0 & & & & & & & \\
\hline \multicolumn{9}{|l|}{$\begin{array}{l}\text { Centro Ginecológico Bolonia (http:// } \\
\text { www.ginecologiabolonia.es)/ }\end{array}$} \\
\hline $\begin{array}{l}\text { IRAGA UR Asistida La Rosaleda } \\
\text { (http://www.iraga.net/es/ }\end{array}$ & 45.0 & & & & & 90.0 & & \\
\hline $\begin{array}{l}\text { Clínica Eugin } \\
\text { (https://http://www.eugin.es)/ }\end{array}$ & & 71.0 & 52.0 & 37.0 & 65.0 & & & \\
\hline $\begin{array}{l}\text { AisaFiv } \\
\text { (http://www.aisafiv.com)/ }\end{array}$ & 48.6 & 55.0 & 50.0 & 33.3 & 66.7 & & & \\
\hline $\begin{array}{l}\text { CARE Clínica Ginecológica (http:// } \\
\text { www.careclinica.es)/ }\end{array}$ & 45.0 & & & & 60.0 & & & \\
\hline $\begin{array}{l}\text { IVI } \\
\text { (http://www.ivi.es)/ }\end{array}$ & 53.6 & 63.9 & 54.4 & 45.0 & 68.9 & 90.0 & $\mathrm{X}$ & \\
\hline $\begin{array}{l}\text { Centro Ginecológico de León } \\
\text { (http://www.centrogine.es)/ }\end{array}$ & 45.0 & & & & & & & \\
\hline $\begin{array}{l}\text { CER Santander } \\
\text { (http://www.cersantander.com)/ }\end{array}$ & 50.0 & & & 33.3 & & & & \\
\hline $\begin{array}{l}\text { UltraFiv-Bahía (http://www. } \\
\text { ultrafivbahia.com)/ }\end{array}$ & 46.4 & & & & 62.3 & & & \\
\hline $\begin{array}{l}\text { Clínica Imar } \\
\text { (http://www.clinicaimar.com)/ }\end{array}$ & & 60.0 & 56.0 & 31.0 & 80.0 & & & \\
\hline
\end{tabular}


Analysis of the truth in advertising on the efficacy provided by assisted reproduction clinics - Juan Aznar et al.

\begin{tabular}{|c|c|c|c|c|c|c|c|c|}
\hline \multirow[b]{2}{*}{ PRIVATE AHRC } & \multicolumn{4}{|l|}{1} & \multirow{2}{*}{\begin{tabular}{|l|}
2 \\
$(\%)$
\end{tabular}} & \multirow{2}{*}{\begin{tabular}{|l|}
3 \\
$(\%)$
\end{tabular}} & \multirow{2}{*}{\begin{tabular}{|l|}
4 \\
$(\%)$
\end{tabular}} & \multirow{2}{*}{\begin{tabular}{|l|}
5 \\
$(\%)$
\end{tabular}} \\
\hline & \begin{tabular}{|l|l} 
Overall \\
$(\%)$
\end{tabular} & \begin{tabular}{|l|}
$<35$ \\
years $(\%)$
\end{tabular} & \begin{tabular}{|l}
$\begin{array}{l}35-39 \text { years } \\
(\%)\end{array}$ \\
\end{tabular} & \begin{tabular}{|l|}
$\geq 40$ \\
years $(\%)$
\end{tabular} & & & & \\
\hline $\begin{array}{l}\text { CERAM -Centro de RA de Marbella } \\
\text { (http://www.ceram.es)/ }\end{array}$ & 67.0 & & & & 70.0 & & & \\
\hline $\begin{array}{l}\text { Clínica Fertia (http://www. } \\
\text { clinicafertia.com)/ }\end{array}$ & 50.0 & 75.0 & 29.0 & 12.0 & 60.0 & & $\mathrm{X}$ & \\
\hline $\begin{array}{l}\text { FertiMed (http://www. } \\
\text { fertimed.info/index.php/es/ }\end{array}$ & & & & & 60.0 & & & \\
\hline $\begin{array}{l}\text { Invitam } \\
\text { (http://www.invitam.es)/ }\end{array}$ & 50.0 & 70.0 & 70.0 & & 85.7 & & & \\
\hline $\begin{array}{l}\text { Instituto Canario de Infertilidad } \\
\text { (ICI) (http://www.icinfertilidad. } \\
\text { com)/ }\end{array}$ & 44.8 & & & & 57.6 & & & \\
\hline $\begin{array}{l}\text { Clínica Rubal } \\
\text { (http://www.rubal.es)/ }\end{array}$ & 40.8 & & 46.1 & & 64.0 & & & \\
\hline $\begin{array}{l}\text { URH García del Real } \\
\text { (http://www.urh.es)/ }\end{array}$ & 43.0 & 57.0 & 38.0 & 19.0 & 61.0 & 83.0 & $\mathrm{X}$ & \\
\hline $\begin{array}{l}\text { Instituto de Fertilidad (IF) (http:// } \\
\text { www.institutodefertilidad.es)/ }\end{array}$ & 51.0 & & & & & 98.0 & & \\
\hline $\begin{array}{l}\text { Instituto de Fertilidad Rincón } \\
\text { (http://www.fertilidad.clinicasrincon. } \\
\text { com)/ }\end{array}$ & & 45.0 & 52.0 & 47.0 & 64.0 & & & \\
\hline $\begin{array}{l}\text { FIV Madrid } \\
\text { (http://www.fivmadrid.es)/ }\end{array}$ & & 62.0 & 50.0 & 34.0 & & 82.0 & $\mathrm{X}$ & \\
\hline $\begin{array}{l}\text { Másvida Reproducción } \\
\text { (http://www.masvidareproduccion. } \\
\text { com)/ }\end{array}$ & 49.2 & 59.1 & 47.1 & 24.2 & 64.9 & & & \\
\hline $\begin{array}{l}\text { Clínica Norba } \\
\text { clinicanorba.com)/ }\end{array} \quad$ (http://www. & 50.0 & & & & & & & \\
\hline $\begin{array}{l}\text { Fertilab } \\
\text { (http://www.fertilab.com)/ }\end{array}$ & & & & & & & $\mathrm{X}$ & \\
\hline $\begin{array}{l}\text { Centro de infertilidad - Doctora } \\
\text { Irene Matarranz (http://www. } \\
\text { doctorairenematarranz.com)/ }\end{array}$ & 35.0 & & & & & 70.0 & & \\
\hline $\begin{array}{l}\text { Roquetas FIV (http://www. } \\
\text { roquetasfiv.com)/wordpress/ }\end{array}$ & 33.9 & & & & & 80.0 & & \\
\hline $\begin{array}{l}\text { FIV Barcelona (http://www. } \\
\text { fivbarcelona.org/ }\end{array}$ & 50.0 & & & & & & & \\
\hline $\begin{array}{l}\text { Unitat Endocrinologia Ginecològica } \\
\text { (Ueg) (http://www.uegclinic. } \\
\text { cat/ }\end{array}$ & 55.3 & & & & 75.2 & 85.0 & & \\
\hline $\begin{array}{l}\text { F. Puigvert-Hospital de la Santa Cruz } \\
\text { y San Pablo (http://www.fundacio- } \\
\text { puigvert.es)/ }\end{array}$ & 47.0 & & & & & & & \\
\hline $\begin{array}{l}\text { FIV Clínic } \\
\text { (http://www.hospitalclinic.org/ }\end{array}$ & 45.6 & & & & & & & \\
\hline $\begin{array}{l}\text { Institut Dexeus } \\
\text { (http://www.dexeus.com)/ }\end{array}$ & 45.0 & 55.0 & & 25.0 & 60.0 & 80.0 & & \\
\hline $\begin{array}{l}\text { Àptima Centre Clínic MútuaTerrassa } \\
\text { (http://www.aptimacentreclinic. } \\
\text { com)/ }\end{array}$ & 50.0 & & & & & & & \\
\hline
\end{tabular}


Acta Bioethica 2017; 23 (2): 311-325

\begin{tabular}{|c|c|c|c|c|c|c|c|c|}
\hline \multirow[b]{2}{*}{ PRIVATE AHRC } & \multicolumn{4}{|l|}{1} & \multirow{2}{*}{2} & \multirow{2}{*}{3} & \multirow{2}{*}{$\begin{array}{l}4 \\
(\%)\end{array}$} & \multirow{2}{*}{$\begin{array}{l}5 \\
(\%)\end{array}$} \\
\hline & $\begin{array}{l}\text { Overall } \\
(\%)\end{array}$ & $\begin{array}{l}<35 \\
\text { years }(\%)\end{array}$ & $\begin{array}{l}35-39 \text { years } \\
(\%)\end{array}$ & $\begin{array}{l}\geq 40 \\
\text { years }(\%)\end{array}$ & & & & \\
\hline $\begin{array}{l}\text { Clínica Ruber Internacional } \\
\text { (http://www.unidaddelamujer.es)/ } \\
\text { ginecologia/ginecologia/\# }\end{array}$ & 60.0 & & & & 70.0 & & & \\
\hline $\begin{array}{l}\text { Hospital Universitario Sanitas La } \\
\text { Zarzuela (http://www.sanitas.es)/ } \\
\text { sanitas/seguros/es/particulares/ } \\
\text { medicosycentros/hospital_zarzuela/ } \\
\text { index.html }\end{array}$ & & & & & & & $\mathrm{X}$ & \\
\hline $\begin{array}{l}\text { Instituto Europeo de Fertilidad } \\
\text { (http://www.iefertilidad.com)/ }\end{array}$ & & & & & & 84.9 & $\mathrm{X}$ & \\
\hline $\begin{array}{l}\text { IBILAB (Instituto Balear de } \\
\text { Infertilidad) (http://www. } \\
\text { ibi-es.com)/ }\end{array}$ & 46.0 & & & & 74.0 & & & \\
\hline $\begin{array}{l}\text { Centro de Asistencia a la RH de } \\
\text { Canarias (FIVAP) (http://www.fivap. } \\
\text { com)/ }\end{array}$ & 40.0 & & & & 62.0 & & & \\
\hline $\begin{array}{l}\text { Ginemed } \\
\text { (https://http://www.ginemed.es)/ }\end{array}$ & 44.9 & & & & 61.8 & 83.0 & & \\
\hline $\begin{array}{l}\text { Centro Médico Teknon (http://www. } \\
\text { teknon.es)/web/reproduccion-asistida }\end{array}$ & 40.0 & 39.0 & 27.0 & 15.0 & & & & \\
\hline Mean rate & 47.2 & 59.0 & 47.4 & 30.7 & 65.0 & 85.3 & & \\
\hline
\end{tabular}

Notes:

1: Pregnancy rate per stimulation cycle with autologous oocytes

2: Pregnancy rate per stimulation cycle with donor oocytes

3: Cumulative pregnancy rate.

4: Guarantee that the patient can become pregnant and have a child

5: Can resolve all infertility issues

Note: A total of 169 websites representing 278 AHRCs were reviewed, 232 of which were private and 46 public. Only those clinics that provide information on any of the indices shown in the table are listed. Data consulted between 19th and 29th May, 2015. 
stimulation cycle varies between $28 \%$ and 72.2 $\%$, with a mean rate of $47.2 \%$.

These rates for women under 35 years range from $39.0 \%$ to $82.4 \%$, with a mean rate of $59.0 \%$; for those aged 35 to 39 years, they range from $27.0 \%$ to $77.8 \%$, with a mean rate of $47.4 \%$; and for those older than 40 years, the rates range from $12.0 \%$ to $48.6 \%$, with a mean rate of 30.7 $\%$.

When donor oocytes are used, the rates — as can be seen in Table 5 - are better, with a mean of $65.0 \%$, as would be expected when the woman's age does not affect the outcomes. What is surprising though is the high $\mathrm{CPR}$, which ranges from $75 \%$ to $98 \%$, with a mean of $85.3 \%$.

All these data are those presented explicitly by the AHRCs on their websites. In our opinion, however, the most startling claims are those that make reference to comments or statements that could be labelled as more commercial. Here, we refer to statements from those clinics that guarantee that the couple will have a child (Table 5 , column 4), i.e. that they are $100 \%$ effective, and other comments stating that they can provide solutions to any infertility issues (Table 5, column 5).

\section{Discussion}

To compare the success rates that private AHRCs in Spain claim on their websites and brochures with the data that these same clinics provide to the different scientific entities and professional associations, we carried out three types of analysis. Firstly, we evaluated the PR and LBR per stimulation cycle following IVF or ICSI for Spain and Europe, from data provided by scientific associations such as the SEF and ESHRE. Secondly, we obtained the cumulative data for these same rates in Spain, Europe and the rest of the world; and thirdly, we reviewed the outcomes that Spanish AHRCs profess to their clients on their websites and brochures, with special emphasis on their success rates, i.e. the likelihood that women attending them will have a child, since this is the main reason for attracting clients (offering them a high probability of having a child). In our opinion, technically, this success rate is equivalent to the CLBR. Accordingly, it is this rate on which most emphasis will be placed in this study.

\section{Pregnancy and live birth rate per cycle of IVF or ICSI}

If we consider European data (Table 1), the mean PR obtained using IVF after one stimulation cycle is $26.41 \%$, with a LBR of $18.81 \%$. The latter is the most significant, since in reality it is the one that translates into the likelihood that a European woman has of achieving a live birth after a single stimulation cycle.

When the number of live births using ICSI was evaluated (also after one stimulation cycle) (Table 1), the mean PR was $27.22 \%$ and the LBR was $18.31 \%$.

When we looked at ESHRE data for IVF in Spain for the 14 years between 1997 and 2010 (Table 2 ), the PR after a single stimulation cycle was found to range between $23.2 \%$ and $35.0 \%$, with a mean of $30.55 \%$, while the CLBR, also after a single stimulation cycle, ranged between 10.4 $\%$ and $30.6 \%$, with a mean rate of $18.65 \%$. As already mentioned, though, the LBR per stimulation cycle is not the same as the outcomes provided by the clinics for the likelihood that a woman will have a child (since this may be achieved after three or more stimulation cycles), but it is a figure that brings us closer to that reality.

Nevertheless, in relation thereto, if the likelihood of having a child following one stimulation cycle is, for example, $35 \%$, one might think that after three stimulation cycles, this likelihood could reach or exceed $75 \%$. However, this is not apparent in reality, because as mentioned earlier, as the number of stimulation cycles increases, the number of live births achieved after the first, second and third (or even more) cycles increases very little with respect to that achieved in the first cycle(24). We therefore consider that the index that provides information closest to reality is the LBR after three stimulation cycles. Moreover, this is the practice generally followed in most clinics.

In this respect, according to SEF data, the CLBR in Spanish AHRC after three stimulation cycles rarely exceeds $50 \%(15)$. 
When the data obtained using ICSI were evaluated, the outcomes were very similar to those achieved with IVF (Table 2).

When data for Spain were analysed using the information provided by the SEF, the outcomes were akin to those in the EHSRE reports, and as such very similar comments can be made in both cases.

Most interestingly with respect to Spain, we found that in the last years analysed (2011 and 2012), neither rate varied much (and in fact they even fell), meaning that the efficacy of the techniques has not improved recently(15).

Outcomes using ICSI were very similar to those for IVF, so the comments are equally applicable.

\section{Cumulative live birth rates}

The CLBRs (Tables 3 and 4), together with evaluation of the data provided on the AHRC websites (Table 5), are of particular interest, since these rates are the ones that will undoubtedly translate into the real likelihood that a woman attending a AHRC will have a child; moreover, the latter are the figures that clinic websites show their potential clients.

Although there is a large variation in the CLBR of the different countries for which data are presented in the study by Ishihara et al.(30) — ranging from $18.3 \%$ for Italy to $41.8 \%$ for the United States - the figures in Table 3 (which provides data from 13 different studies) show an overall mean LBR of $56.3 \%$, if outcomes from the four studies that provide this information are included. This value is much higher than the percentage obtained for Spain, with $22.9 \%$ in one of the studies(30), and $18.65 \%$ (IVF) and 19.40 $\%$ (ICSI) according to the ESHRE, as the mean value for the period 1997-2010 (Table 2).

\section{Data provided by Spanish AHRC on their web- sites}

A total of 169 websites were evaluated out of a total of 278 AHRC (232 private and 46 public clinics). Table 5 includes the PR per stimulation cycle when autologous oocytes were used, and ranges between $28 \%$ and $72.2 \%$, with an overall mean rate of $47.2 \%$.
When donor oocytes are used, the rates were higher, varying between $44.4 \%$ and $85.7 \%$, with a mean rate of $65.0 \%$. The mean CPR will be higher than the mean LBR, as this is what usually occurs, as can be seen in the ESHRE data shown in Tables 1 and 2.

It is particularly striking that the CLBR is not publicised by any of the private clinics reviewed.

It should also be highlighted that the overall PR reported by these private clinics on their websites for one stimulation cycle ranges between $28.0 \%$ and $72.2 \%$, with a mean value of $47.2 \%$ when autologous oocytes are used, and $65.0 \%$ when donor oocytes are used (Table 5). When this rate -for the same clinics- was evaluated from SEF data, the PR was $30.55 \%$ for IVF and $32.59 \%$ for ICSI (Table 2), meaning that the mean efficacy outcomes reported on the websites of the Spanish AHRC analysed are $49.5 \%$ higher than those of the SEF and ESHRE in one stimulation cycle with autologous oocytes, and up to $108.9 \%$ higher when donor oocytes are used.

This finding certainly supports our thesis that many Spanish AHRC present statistics on their websites that are very far removed from those provided by official sources.

Another notable aspect is that 16 of these clinics expressly state on their websites and brochures that they guarantee that women attending them will become pregnant, which would mean a 100 $\%$ success rate.

It should also be highlighted that some of these clinics state that they can resolve all their clients' fertility issues, and at the same time have been audited by companies or institutions of proven good standing. Finally, many of them also state that they use the most advanced technology.

\section{Conclusion}

Many Spanish AHRCs present data on their websites that are not consistent with those obtained from official ESRHE or SEF reports. This is first of all because they do not report data on live births, which is the rate that best matches the real likelihood that assisted reproduction treatments 
Analysis of the truth in advertising on the efficacy provided by assisted reproduction clinics - Juan Aznar et al.

will eventually lead to the goal of parenthood. This, of course, is what clients seek in these clinics. With respect to the PR published by Spanish AHRCs on their websites, the data differ openly from those reported by the ESHRE and SEF, professing mean efficacy outcomes $49.5 \%$ higher than official reports in a stimulation cycle with autologous oocytes, and up to $108.9 \%$ higher when donor oocytes are used.
Statements guaranteeing that $90 \%$ of women will reach their objective of having a child are particularly noteworthy. This, in our opinion, can constitute false advertising, something that merits a very negative ethical rating.

\section{References}

1. Nygren KG, Andersen AN. Assisted reproductive technology in Europe, 1997. Results generated from European registers by ESHRE. Human Reproduction 2001; 16(2): 384-391.

2. Nygren KG, Andersen AN. Assisted reproductive technology in Europe, 1998. Results generated from European registers by ESHRE. Human Reproduction 2001; 16(11): 2459-2471.

3. Nygren KG, Andersen AN. Assisted reproductive technology in Europe, 1999. Results generated from European registers by ESHRE. Human Reproduction 2002; 17(12): 3260-3274.

4. Andersen AN, Gianaroli L, Nygren KG. Assisted reproductive technology in Europe, 2000. Results generated from European registers by ESHRE. Human Reproduction 2004; 19(3): 490-503.

5. Andersen AN, Gianaroli L, Felberbaum R, et al. Assisted reproductive technology in Europe, 2001. Results generated from European registers by ESHRE. Human reproduction 2005; 20(5): 1158-1176.

6. Andersen AN, Gianaroli L, Felberbaum R, et al. Assisted reproductive technology in Europe, 2002. Results generated from European registers by ESHRE. Human Reproduction 2006; 21(7): 1680-1697.

7. Andersen A, Goossens V, Gianaroli L, Felberbaum R, De Mouzon J, Nygren K. Assisted reproductive technology in Europe, 2003. Results generated from European registers by ESHRE. Human Reproduction 2007; 22(6): 1513-1525.

8. Andersen A, Goossens V, Ferraretti A, Bhattacharya S, Felberbaum R, De Mouzon J, et al. Assisted reproductive technology in Europe, 2004: results generated from European registers by ESHRE. Human Reproduction 2008; 23(4): 756-771.

9. Andersen A, Goossens V, Bhattacharya S, Ferraretti A, Kupka M, De Mouzon J, et al. Assisted reproductive technology and intrauterine inseminations in Europe, 2005: results generated from European registers by ESHRE. Human Reproduction 2009; 24(6): 1267-1287.

10. De Mouzon J, Goossens V, Bhattacharya S, Castilla J, Ferraretti A, Korsak V, et al. Assisted reproductive technology in Europe, 2006: results generated from European registers by ESHRE. Human Reproduction 2010; 25(8): 1851-1862.

11. De Mouzon J, Goossens V, Bhattacharya S, Castilla J, Ferraretti A, Korsak V, et al. Assisted reproductive technology in Europe, 2007: results generated from European registers by ESHRE. Human Reproduction 2012; 27(4): 954-966.

12. Ferraretti A, Goossens V, De Mouzon J, Bhattacharya S, Castilla J, Korsak V, et al. Assisted reproductive technology in Europe, 2008: results generated from European registers by ESHRE. Human Reproduction 2012; 27(9): 2571-2584.

13. Ferraretti A, Goossens V, Kupka M, Bhattacharya S, de Mouzon J, Castilla J, et al. Assisted reproductive technology in Europe, 2009: results generated from European registers by ESHRE. Human Reproduction 2013; 28(9): 2318-2331.

14. Kupka MS, Kupka MS, Ferraretti AP, et al. Assisted reproductive technology in Europe, 2010: results generated from European registers by ESHRE. Human Reproduction 2014; 29: 2099-2113.

15. Sociedad Española de Fertilidad. Registro SEF 2014 (cited 2015 12 10). Available from: https://www.registrosef.com/ index.aspx?ReturnUrl=\%2f\#Anteriores.

16. FIVNAT French In Vitro National F. Pregnancies and births resulting from in vitro fertilization: French National IVF Registry: analysis of data 1986 to 1990. Fertil Steril 1995; 64(4): 746-756.

17. Klipstein S, Regan M, Ryley DA, et al. One last chance for pregnancy: a review of 2,705 in vitro fertilization cycles initiated in women age 40 years and above. Fertil Steril 2005; 84: 435-445.

18. Tan S, Royston P, Campbell S, et al. Cumulative conception and livebirth rates after in-vitro fertilisation. The Lancet 1992; 339 . 
19. Engmann L, Maconochie N, Bekir JS, et al. Cumulative probability of clinical pregnancy and live birth after a multiple cycle IVF package: a more realistic assessment of overall and age-specific success rates? Br J Obstet Gynaecol 1999; 106: 165-170.

20. Stolwijk AM, Wetzels AM, Braat DD. Cumulative probability of achieving an ongoing pregnancy after in-vitro fertilization and intracytoplasmic sperm injection according to a woman's age, subfertility diagnosis and primary or secondary subfertility. Human Reproduction 2000; 1: 203-209.

21. Kovacs G, Maclachlan V, Brehny S. What is the probability of conception for couples entering an IVF program? Aust NZ J Obstet Gynaecol 2001; 41(2): 207-209.

22. Schröder AK, Katalinic A, Diedrich K, et al. Cumulative pregnancy rates and drop-out rates in a German IVF programme: 4102 cycles in 2130 patients. Reprod Biomed Online 2004; 8(5): 600-606.

23. Pelinck MJ, Knol HM, Vogel NE, et al. Cumulative pregnancy rates after sequential treatment with modified natural cycle IVF followed by IVF with controlled ovarian stimulation. Human Reproduction 2008; 23: 1808-1814.

24. Stern JE, Brown MB, Luke B, et al. Calculating cumulative live-birth rates from linked cycles of assisted reproductive technology (ART): data from the Massachusetts SART CORS. Fertility and Sterility 2010; 94(4): 1334-1340.

25. Gnoth C, Maxrath B, Skonieczny T, Friolm K, Godehardt E, Tigges J. Final ART success rates: a 10 years survey. Human Reproduction 2011; 26: 2239-2246.

26. Levi-Setti PE, Albani E, Matteo M, Morenghi E, Zannoni E, Baggiani A, et al. Five years (2004-2009) of a restrictive law-regulating ART in Italy significantly reduced delivery rate: analysis of 10706 cycles. Human Reproduction. 2013; 28: 343-349.

27. Malizia BA, Dodge LE, Penzias AS, et al. The cumulative probalility of liveborn multiples after in vitro fertilization: a cohort study of more than 10,000 women. Fertility and Sterility 2013.

28. Stern JE, Brown MB, Wantman E, et al. Live birth rates and birth outcomes by diagnosis using linked cycles from the SART CORS database. Journal of Assisted Reproduction and Genetics 2013; 30(11):1445-50.

29. Smith A, Tilling K, Nelson SM, et al. Live-birth rate associated with repeat in vitro fertilization treatement cycles. JAMA 2015; 314(24): 2654-2662.

30. Ishihara O, Adamson GD, Dyer S, et al. International Committe for Monitoring Assisted Reproductive Technologies: World Report on Assisted Reproductive Technologies, 2007. Fertility and Sterility 2015; 103: 403-413.

31. Gelbaya TA, Tsoumpou I, Nardo LG. The likelihood of live birth and multiple birth after single versus double embryo transfer at the cleavage stage: a systematic review and meta-analysis. Fertility and Sterility 2010; 94: 936-945.

32. Thurin A, Hausken J, Hillensjö T, et al. Elective single-embryo transfer versus double-embryo transfer in in vitro fertilization. N Engl J Med 2004; 351: 2392-2402.

33. Lukassen HG, Braat DD, Wetzels AM, et al. Two cycles with single embryo transfer versus one cycle with double embryo transfer: a randomized controlled trial. Human Reproduction 2005; 20: 702-708.

34. Moustafa MK, Sheded AS, El Aziz Mousta MA. Elective single embryo transfer versus double embryo transfer in assisted reproduction. Reproduction Biomedicine 2008; 17: 82-87.

35. Heijnen E. Novel paradigms in succesful IVF treatment. (Online). Utrecht University: Igitur, Utrecht Publishing \& Archiving Services; 2006. Available from: http://dspace.library.uu.nl/bitstream/handle/1874/12620/?sequence=6.

36. Luke B, Brown MB, Wantman E, et al. Cumulative Birth Rates with Linked Assisted Reproductive Technology Cycles. The New England Journal of Medicine 2012; 366: 2483-2491.

37. HU Virgen de las Nieves. Memoria de actividades. [Online].; 2014 [cited 201506 23. Available from: http://www.hvn. es/servicios_asistenciales/unidad_de_reproduccion/ficheros/memoria2014.pdf

Received: September 16, 2016

Accepted: May 2, 2017 